\title{
Diagnostic and prognostic role of serum Ki-67 and HE4 levels in Egyptian breast cancer patients
}

\section{Al-Shimaa M. Abas ${ }^{1}$, Mohamed H Sherif ${ }^{2}$ and Sara A. Elmoneam Farag ${ }^{1}$}

${ }^{1}$ Biochemistry Division, Chemistry Department, Faculty of Science, Zagazig University, Zagazig, Egypt.

${ }^{2}$ Organic Chemistry, Chemistry Department, Department, Faculty of Science, Zagazig University, Zagazig, Egypt.

\begin{tabular}{l}
\hline A R T I C L E I N F O \\
\hline Article history: \\
Received : 11/1/2021 \\
Accepted : 5/3/2021 \\
Available online :9/3/2021
\end{tabular}

Keywords:

Breast cancer (BC), Ki-67, HE4, clinicopathological parameters.

\begin{abstract}
A B S T R A C T
Background: Breast cancer (BC) is the most common cancer in women and is the second most common cause of fatality in patients with cancer in the world. Tumor biomarkers have significant role in diagnosis and predicting the prognosis and decide the specific therapy to each patient. Aim: This study aims to evaluate the value of serum Ki-67 and Human epididymis protein 4 (HE4) as a diagnostic and prognostic markers in breast cancer patients and to analyze the associations these markers and their clinicopathological parameters. Subjects \& Methods: This study included 120 patients with breast cancer and 30 healthy served as controls. We measured the serum level of Ki-67 and HE4 by ELISA technique. Results: Our results showed that there were statistically significant differences in serum $\mathrm{Ki}-67$ and HE4 levels between two groups. Also, in breast cancer patients, there was significant difference between Ki-67 level, the same results with HE4 level and patient's age, tumor size, lymph node and metastasis. No significant relationship was found between Ki-67 level and tumor grade, ER, PR and HER2. The cutoff value for the prediction of breast cancer was determined at $>2.48 \mathrm{ng} / \mathrm{ml}$ for $\mathrm{Ki}-67$ and $>25.2 \mathrm{pmol} / \mathrm{L}$ for HE4 with a sensitivity of $98.3 \%, 100 \%$, specificity of $96.7 \%$, 96.7\%, positive predictive value of $98.3 \%, 98.3 \%$, negative predictive value of $96.7 \%, 100 \%$ and accuracy of $88 \%, 98.9 \%$ respectively. In conclusion: serum Ki-67 and HE4 can be used as strong diagnostic markers for breast cancer.
\end{abstract}

(c) Publisher All rights reserved 2021.

\section{INTRODUCTION}

Breast cancer (BC) is one of the most common cancers worldwide in women [1].
Tumor markers are substances produced by the tumors or by other cells of the body in response to cancer or certain benign

Corresponding author: Al-Shimaa Mahmoud Abas, Biochemistry Division, Chemistry department, Faculty of Science,

Zagazig University, Egypt. Email: dr_shmma@yahoo.com, mobile:01009890366. 
conditions. They are produced at much higher levels in cancerous conditions [2].

Biomarkers can be prognostic, predictive, or both. Prognostic biomarkers measure prognosis independently of other factors. The finding or absence of these markers is directly related to recurrence or mortality of disease. Markers can predict if or not a patient will respond to a given therapy [3]. For many years, tumor size, axillary lymph node status, histological characteristics of the tumor (especially histological grade of malignancy and invasion of lymphatic vessels), estrogen receptor (ER), progesterone receptor (PR), human epidermal growth factor receptor-2 (HER2) and patient's age were used to evaluate the prognosis and to determine the appropriate treatment strategy for breast cancer patients [4].

Cell proliferation has an important role in the clinical behavior of invasive breast cancer. High cell proliferation is related to poor prognosis of disease. $\mathrm{Ki}^{-} 67$ protein is encoded by MK167 gene and is a cellular marker for proliferation in humans. This is a nuclear protein and is expressed in proliferating cells but is not detected in resting cells [5].

Human epididymal protein 4 (HE4) is a secretory protein firstly known in human epididymis epithelial cells [6]. HE4 was expressed in number types of normal human tissues it is expression was significantly showed in a number of malignant tumors, specially gynecological, pulmonary, gastrointestinal and breast tissue; however, the Serum levels and their diagnostic and prognostic value remain to be elucidated in breast cancer [7].

The aim of the present study was to evaluate the association between the serum expression levels of $\mathrm{Ki}-67, \mathrm{HE} 4$ as prognostic markers by ELISA technique and the clinicopathological variables, and to assess the potential use of these markers for the diagnosis of breast cancer.

\section{Patients and methods}

This study included 30 healthy individuals and 120 patients with breast cancer admitted to Clinical Oncology and Internal Medicine Outpatient Clinics of Zagazig University Hospital. The data of this analytical descriptive study were obtained from patient's documents. The presence of estrogen receptor (ER), progesterone receptor (PR), human epidermal growth factor receptor-2 (HER2), lymph node (LN) status, tumor grades and sizes were determined after diagnosis. The grade of tumors was confirmed by an expert pathologist, and the lymph node status was confirmed clinically using imaging techniques after surgery. The criteria for selecting the patients were, (a) Presence of breast lump which was diagnosed as breast carcinoma (b) No systemic disease such as diabetes mellitus, hypertension, chronic inflammatory disease, liver, renal or heart failure. The data recorded are partly presented in Table 1.

\section{Blood sampling}

Fasting venous blood samples were collected from all participants. Within 30 min, the sera were separated by centrifugation at $3000 \mathrm{rpm}$ for $10 \mathrm{~min}$ after a minimum time span of $30 \mathrm{~min}$ and serum were removed, aliquot, and stored at -80 ${ }^{0} \mathrm{C}$ until further processing.

\section{Measurement of circulating Human Ki- 67 and Human epididymal protein 4 (HE4) level.}

Serum concentration of Ki-67 and Human epididymal protein 4 (HE4) was measured using a commercially available ELISA kit purchased from (Sun Red company) catalog number 201-12-5320 \& 201-125498 respectively.

\section{Statistical analysis}

Data were analyzed in SPSS 16.0. The analysis of variance (ANOVA) evaluated the relationship between the $\mathrm{Ki}-67$ and HE4 with clinicopathologic factors. A probability $\mathrm{p}$-value $<0.05$ was considered 
statistically significant. The data reported as means \pm standard deviation.

\section{Results}

\section{Baseline clinical and pathological data}

A total of 120 newly diagnosed breast cancer patients were enrolled in this study. The characteristics of these patients were shown in Table $1.10 \%$ of patients were less than 40 years old and $90 \%$ were equal or more than 40 years old. Tumors were ER-positive in $43.3 \%$ of cases and presented PR positivity in $33.3 \%$ of the analyzed samples. In $11.6 \%$ of cases HER2 positivity was detected.

Patients showed tumor size T0-T1 (20\%), T2 $(20 \%)$, T3 $(20 \%)$, T4 (40\%) of cases. Tumor lymph node was N0 (6.7 \%), N1 (40\%), N2 (11.7\%), N3 (38.3\%) of patients. Based on histological grading results about $1.7 \%$ of patients were G1, G2 (71.7 \%), G3 (10 \%). Metastasis was observed in $20 \%$ of cases (metastasize to lung, bone, liver and some cases metastasized to two organs).

\section{Relationship between serum level of Ki- 67 and clinicopathological characteristic of breast cancer cases.}

Our results presented in Table 2 showed significant difference between Ki-67 level and patient's age $(\mathrm{p}<0.05)$, tumor size $(\mathrm{p}<$ $0.001)$, lymph node ( $\mathrm{p}<0.05)$ and metastasis ( $p<0.001)$. No significant relationship was found between $\mathrm{Ki}-67$ level and tumor grade, ER, PR and HER2 (p>0.05).

Relationship between serum level of Human epididymal protein 4 _(HE4) and clinicopathological characteristic of breast cancer cases.

Our results presented in Table 3 showed significant difference between HE4 level and patient's age $(\mathrm{p}<0.05)$, tumor size $(\mathrm{p}<$ 0.001), lymph node ( $\mathrm{p}<0.01$ ) and metastasis ( $\mathrm{p}<$ 0.001). No significant relationship was found between HE4 level and tumor grade, ER, PR and HER2 (p> $0.05)$.
Serum level of Ki-67 and Human epididymal protein 4 (HE4) in healthy control and breast cancer patients.

Results in table 4 documented that there was significant difference between the mean levels of Ki-67 (1.9 $\pm 0.25 \mathrm{ng} / \mathrm{ml})$ and HE4 (19.4 $2.7 \mathrm{pmol} / \mathrm{L})$ in healthy control and breast cancer patients $(6.1 \pm 2.3$ $\mathrm{ng} / \mathrm{ml}) \&(86.6 \pm 32.1 \mathrm{pmol} / \mathrm{L})$ respectively $(\mathrm{p}<0.001)$.

Correlation analysis between all the parameters under study.

Our data showed that there was no correlation between Ki-67 and age, tumor grade, ER, PR and HER2. Also, found positive relationship between $\mathrm{Ki}-67$ and tumor size $(\mathrm{r}=0.810)$, lymph node $(\mathrm{r}=0.290)$, metastasis $(\mathrm{r}=0.610)$ and strong positive relationship with HE4 $(r=0.958)$ (Table 5).

Also, our data showed that there was no correlation between HE4 and age, tumor grade, ER, PR and HER2. Also, found positive relationship between HE4 and tumor size $(\mathrm{r}=0.883)$, lymph node $(\mathrm{r}=0.348)$ and metastasis $(\mathrm{r}=0.677)$.

Defining cut-off points for serum level of Ki-67 and HE4

The cutoff value of Ki-67 and HE4 levels for predicting breast cancer was determined by ROC analysis. The cutoff value for the prediction of breast cancer was determined at $>2.48 \mathrm{ng} / \mathrm{ml}$ for Ki-67 with a sensitivity of $98.3 \%$, specificity of $96.7 \%$, positive predictive value of 98.3 $\%$, negative predictive value of $96.7 \%$ and accuracy of $88 \%$ [AUC, 0.996] (Figure 1). Also, The cutoff value for the prediction of breast cancer was determined at $>25.2$ pmol/L for HE4 with a sensitivity of 100 $\%$, specificity of $96.7 \%$, positive predictive value of $98.3 \%$, negative predictive value of $100 \%$ and accuracy of 98.9\% [AUC, 0.100] (Figure 2). 


\section{Discussion}

Breast cancer is the most common female cancer in the world. It is a heterogeneous group of diseases that differs in their pathological characteristics and clinical presentation, thus it is important to find good prognostic markers that can define patients who are at high risk of recurrence and choosing the suitable therapy for them [8].

The risk of recurrence and prognosis are affected by the stage at diagnosis and biological features of the tumor. The main purpose for breast cancer diagnosis is to improve the accuracy of biomarkers for detection of disease at the early stage.

Prognostic markers such tumor size, grade, age, histological type and estrogen receptor status influence the therapy decision. Cell proliferation is one of the most important features of tumor; so, its measurement may give useful data about status of the disease. Ki67 is a marker of cell proliferation and was used to give prognostic values in invasive breast cancer. Number of serum biomarkers was evaluated; although none of these markers was reached the sensitivity and specificity required for either screening or early diagnosis [9].

This study was conducted to evaluate Ki67 and HE4 to determine the prognostic and diagnostic value in patients with breast cancer. In addition, we tried to show the relationship between Ki67, HE4 and prognostic factors and the effect on the outcome of the disease.

Our results presented in Table 2 showed significant increase in Ki-67 level and patient's with age $\geq 40$ year than patients with age $<40$ year $(\mathrm{p}<0.05)$. Also, tumor size $(\mathrm{p}<0.001)$, lymph node $(\mathrm{p}<0.05)$ and metastasis $(p<0.001)$. No significant difference was found between Ki-67 level and tumor grade, ER, PR and HER2 ( $p$ > $0.05)$.

Our data showed that there was no correlation between Ki-67 and age, tumor grade, ER, PR and HER2. Also, found positive relationship between $\mathrm{Ki}-67$ and tumor size $(\mathrm{r}=0.810)$, lymph node $(\mathrm{r}=0.290)$, metastasis $(\mathrm{r}=0.610)$.

These results are in line with who reported that there was no correlation between $\mathrm{Ki}$ 67 and patient's age and grade [10]. Also, who found that there was no significant relationship between the distribution of $\mathrm{Ki}$ 67 and PR ( $\mathrm{p}=0.149)$ and HER2 (p = 0.597 ) [11]. Other study are in line with the data that found tissue $\mathrm{Ki}-67$ expression can give addition prognostic information to that obtained from classical prognostic factors and can provide data of significant value to other important prognostic indicators such as tumor size and lymph node involvement [12].

As shown level of Ki-67 increase with histopathological features (tumor size, lymph node, metastasis), this in line with results of who declared that the high mean score of Ki-67 suggests the aggressive feature of breast cancer [13].

Our results presented in Table 3 showed significant difference between HE4 level and patient's age $(\mathrm{p}<0.05)$, tumor size $(\mathrm{p}<$ 0.001), lymph node ( $\mathrm{p}<0.01)$ and metastasis $(\mathrm{p}<0.001)$. No significant relationship was found between HE4 level and tumor grade, ER, PR and HER2 ( $p>$ $0.05)$.

Also, our data showed that there was no correlation between HE4 and age, tumor grade, ER, PR and HER2. Also, found positive relationship between HE4 and tumor size $(\mathrm{r}=0.883)$, lymph node $(\mathrm{r}=0.348)$ and metastasis $(\mathrm{r}=0.677)$.

Our data are in accordance with who found that HE4 expression is associated with lymph node and metastasis involvement and is a possible predictive factor of breast cancer recurrence. Therefore, it was suggested

that tumor cells expressing these protein families take advantage of the antiproteinase function and act as a defence against the surrounding proteolytic and inflammatory environment [14].

These results opposed with who found that no significant differences were observed between HE4 and clinicopathological 
characteristics of breast cancer and ovarian cancer patients [15] \& [16].

Our results in table 4 documented that there was significant difference between the mean levels of Ki-67 $(1.9 \pm 0.25 \mathrm{ng} / \mathrm{ml})$ and HE4 (19.4 $2.7 \mathrm{pmol} / \mathrm{L})$ in healthy control and breast cancer patients $(6.1 \pm 2.3$ $\mathrm{ng} / \mathrm{ml}) \&(86.6 \pm 32.1 \mathrm{pmol} / \mathrm{L})$ respectively $(\mathrm{p}<0.001)$.

These results are in agreement with who stated that median serum levels of $\mathrm{Ki}-67$ in healthy subjects was $3.92 \quad(2.72-7.29)$ $\mathrm{ng} / \mathrm{ml}$., there was statistically significant difference between healthy control group and breast cancer group $(\mathrm{P}<0.001)$ [12]. This confirmed the diagnostic value of serum Ki-67 for breast cancer.

Also, significant increase of serum HE4 levels in patients with breast cancer compared to healthy controls was found. HE4 may be as a novel marker for diagnosis of breast cancer [15].

We found that the cutoff value for the prediction of breast cancer was determined at $>2.48 \mathrm{ng} / \mathrm{ml}$ for Ki-67 with a sensitivity of $98.3 \%$, specificity of $96.7 \%$, positive predictive value of $98.3 \%$, negative predictive value of $96.7 \%$ and accuracy of $88 \%$ [AUC, 0.996] (Figure 1).

Previous studies agreed that the accuracy, sensitivity, and specificity levels of identifying breast cancer were 89.44, 85.05 , and $95.23 \%$, respectively [17].

Also, The cutoff value for the prediction of breast cancer was determined at $>25.2$ $\mathrm{pmol} / \mathrm{L}$ for HE4 with a sensitivity of 100 $\%$, specificity of $96.7 \%$, positive predictive value of $98.3 \%$, negative predictive value of $100 \%$ and accuracy of 98.9\% [AUC, 0.100] (Figure 2).

This are in line with the another results of who found that the cut off value was determined at $>13.24 \mathrm{pmol} / \mathrm{l}$ for the prediction of breast cancer for HE4, with a sensitivity of $61.11 \%$, specificity of $68.75 \%$, positive predictive value of $81.48 \%$, negative predictive value of $44.0 \%$ and accuracy of $63.46 \%$ and HE4 may serve as a novel biomarker for the diagnosis of breast cancer [15].

\section{Conclusion}

The results of present study support the finding that serum Ki-67 and HE4 level may be considered valuable potential biomarkers and add prognostic information to that obtained from classical prognostic factors such as pathological tumor size, lymph node and metastasis involvement. Also, there is no significant relationship between Ki67, HE4 and some prognostic factors such as hormonal receptors and HER2. Finally serum Ki-67 and HE4 can be used as strong diagnostic markers for breast cancer.

\section{Acknowledgements}

The Authors appreciate Prof. Dr. Wael Hassan El-Sawy, Professor of Clinical Oncolog, Faculty of Medicine, Zagazig University.

\section{References}

1 Ferlay J, Soerjomataram I, Dikshit R., Eser S, Mathers C, Rebelo M, Parkin DM, Forman D and Bray F: Cancer incidence and mortality worldwide. Int J Cancer 136: E359-E386, 2015.

2 Geng B, Liang MM, Ye XB and Zhao WY: Association of CA 15-3 and CEA with clinicopathological parameters in patients with metastatic breast cancer. Mol Clin Oncol 3: 232-236, 2015.

3 Taneja P, Maglic D and Kai F: Classical and novel prognostic markers for breast cancer and their clinical significance. Clin Med Oncol 4:15-34, 2010.

4 Kittaneh M, Montero AJ and Glück S: Molecular pro ling for breast cancer: a comprehensive review. Biomark Cancer 5:61-70, 2013.

5 Jurlkova M, Danihel, Polak and Varga I: Ki67, PCNA, and MCM proteins: markers of proliferation in the diagnosis of breast cancer. Acta Histochem 118(5):544-52, 2016.

6 Galgano MT, Hampton GM and Frierson HF Jr: Comprehensive analysis of HE4 expression in normal and 
malignant human tissues. Mod Pathol 19: 847-853, 2006.

7 O'Neal RL, Nam KT and LaFleur BJ: Human epididymis protein 4 is upregulated in gastric and pancreatic adenocarcinomas. Hum Pathol 44: 734$742,2013$.

8 de Azambuja E, Cardoso F, de Castro G, Colozza Jr M, Mano MS, Durbecq V, Sotiriou C, Larsimont D, PiccartGebhart MJ and Paesmans M. Ki-67 as prognostic marker in early breast cancer: a meta-analysis of published studies involving 12,155 patients. $\mathrm{Br} \mathrm{J}$ Cancer 96(10):1504-13, 2007.

9 Donepudi MS, Kondapalli K, Amos SJ and Venkanteshan P: Breast cancer statistics and markers. J Cancer Res Ther 10: 506-511, 2014.

10 Touraj Asvadi Kermani, Iraj Asvadi Kermani Zhaleh Faham Roya Dolatkhah. Ki-67 status in paients with primary breast cancer and its relationship with other prognostic factors. Biomedical Research and Therapy 6(2):2986-2991, 2019.

11 Aman NA, Doukoure B, Koffi KD, Koui BS, Zie Traore C, Kouyate M, Toure $I$ and Eff AB: Immunohistochemical Evaluation of Ki-67 and Comparison with Clinicopathologic Factors in Breast Carcinomas. Asian Pacific Journal of Cancer Prevention 20 (1): 73-79, 2019.

12 Ragab HM, Samy N, Afify M, Abd El Maksoud $\mathbf{N}$ and Shaaban HM: Assessment of $\mathrm{Ki}-67$ as a potential biomarker in patients with breast cancer. Journal of Genetic Engineering and Biotechnology 16: 479-484, 2018.
13 Nishimura R, Osako $\mathbf{T}$ and Nishiyama Y: Prognostic significance of Ki-67 index value at the primary breast tumor in recurrent breast cancer. Mol Clin Oncol 2: 1062-68, 2014.

14 Kamei M, Yamashita SI, Tokuishi K, Hashioto T, Moroga T, Suehiro M, Ono K, Miyawaki M, Takeno S, Yamamoto S and Kawahara K: HE4 Expression Can Be Associated with Lymph Node Metastases and Disease-free Survival in Breast Cancer. Anticancer Research 30: 4779-4784, 2010.

15 Gunduz UR, Gunaldi M, Isiksacan N, Gunduz S, Okuturlar $Y$ and Kocoglu H: A new marker for breast cancer diagnosis, human epididymis protein 4: A preliminary study. Molecular and Clinical Oncology 5: 355-360, 2016.

16 Akoz G, Diniz G, Ekmekci S, Ekin ZY and Uncel M: Evaluation of human epididymal secretory protein 4 expression according to the molecular subtypes (luminal A, luminal B, human epidermal growth factor receptor 2-positive, triplenegative) of breast cancer. Pathology and Microbiology 61(3): 323-329, 2018.

17 Feng M, Deng Y, Yang L, Jing Q, Zhang Z, Xu L, Wei X, Wu D, Xiang F, Wang $Y$, Bao $J$ and Hong Bu: Automated quantitative analysis of Ki-67 staining and $\mathrm{HE}$ images recognition and registration based on whole tissue sections in breast carcinoma. Diagnostic Pathology 15:65, 2020. 
Table 1: Clinicopathological data of analyzed cases

\begin{tabular}{|c|c|c|c|}
\hline & & Number of cases & $(\%)$ \\
\hline \multirow[t]{2}{*}{ Age } & $<40$ & 12 & $\mathbf{1 0}$ \\
\hline & $\geq 40$ & 108 & 90 \\
\hline \multirow[t]{4}{*}{ Tumor size } & T0-T1 & 24 & 20 \\
\hline & T2 & 24 & 20 \\
\hline & T3 & 24 & 20 \\
\hline & T4 & 48 & 40 \\
\hline \multirow[t]{5}{*}{ Lymph node } & No & 8 & 6.7 \\
\hline & N1 & 48 & 40 \\
\hline & $\mathbf{N 2}$ & 14 & 11.7 \\
\hline & N3 & 46 & 38.3 \\
\hline & Unknown (X) & 4 & 3.3 \\
\hline \multirow[t]{2}{*}{ Metastasis } & Yes & 24 & 20 \\
\hline & No & 96 & 80 \\
\hline \multirow[t]{4}{*}{ Tumor grade } & G1 & 2 & 1.7 \\
\hline & G2 & 86 & 71.7 \\
\hline & G3 & 12 & 10 \\
\hline & Unknown (X) & 20 & 16.6 \\
\hline \multirow{3}{*}{$\begin{array}{l}\text { Estrogen } \\
\text { receptor (ER) }\end{array}$} & Positive & 52 & 43.3 \\
\hline & Negative & 48 & 40 \\
\hline & Unknown (X) & 20 & 16.7 \\
\hline Progesterone & Positive & 40 & 33.3 \\
\hline
\end{tabular}




\begin{tabular}{|l|l|l|l|}
\hline receptor (PR) & Negative & 60 & 50 \\
\cline { 2 - 4 } & Unknown (X) & 20 & 16.7 \\
\hline HER2 & Positive & 14 & 11.7 \\
\cline { 2 - 4 } & Negative & 48 & 40 \\
\cline { 2 - 4 } & Unknown $(X)$ & 58 & 48.3 \\
\hline
\end{tabular}

Table 2: Relation between KI-67 serum level and clinic-pathological characteristic of the 120 studied cases.

\begin{tabular}{|c|c|c|c|}
\hline & & $\begin{array}{c}\text { Serum level } \\
\text { Ki- } 67(\mathrm{ng} / \mathrm{ml}) \\
(\text { Mean } \pm \text { SD) }\end{array}$ & $P$ value \\
\hline \multirow[t]{2}{*}{ Age } & $<40$ & $4.0 \pm 1.5$ & \multirow[t]{2}{*}{0.02} \\
\hline & $\geq 40$ & $6.3 \pm 2.3$ & \\
\hline \multirow[t]{4}{*}{ Tumor size } & T0-T1 & $3.6 \pm 0.5$ & \multirow[t]{4}{*}{0.000} \\
\hline & $\mathbf{T 2}$ & $4.1 \pm 1.3$ & \\
\hline & T3 & $6.0 \pm 1.0$ & \\
\hline & T4 & $8.2 \pm 1.7$ & \\
\hline \multirow[t]{5}{*}{ Lymph node } & No & $3.5 \pm 0.7$ & \multirow[t]{5}{*}{0.02} \\
\hline & N1 & $5.6 \pm 1.9$ & \\
\hline & $\mathbf{N 2}$ & $6.7 \pm 1.6$ & \\
\hline & N3 & $6.9 \pm 2.7$ & \\
\hline & Unknown (X) & $4.0 \pm 0.15$ & \\
\hline \multirow[t]{2}{*}{ Metastasis } & Yes & $8.9 \pm 2.1$ & \multirow[t]{2}{*}{0.000} \\
\hline & No & $5.3 \pm 1.8$ & \\
\hline
\end{tabular}




\begin{tabular}{|c|c|c|c|}
\hline \multirow[t]{4}{*}{ Tumor grade } & G1 & $6.7 \pm 0$ & \multirow[t]{4}{*}{0.89} \\
\hline & G2 & $5.9 \pm 2.3$ & \\
\hline & G3 & $6.7 \pm 1.4$ & \\
\hline & Unknown $(\mathrm{X})$ & $6.1 \pm 2.9$ & \\
\hline \multirow[t]{3}{*}{ Estrogen receptor (ER) } & Positive & $6.4 \pm 2.6$ & \multirow[t]{3}{*}{0.4} \\
\hline & Negative & $6.1 \pm 2.2$ & \\
\hline & Unknown (X) & $5.2 \pm 1.8$ & \\
\hline \multirow{3}{*}{$\begin{array}{l}\text { Progesterone receptor } \\
(\mathrm{PR})\end{array}$} & Positive & $6.2 \pm 2.6$ & \multirow[t]{3}{*}{0.47} \\
\hline & Negative & $6.2 \pm 2.1$ & \\
\hline & Unknown (X) & $5.2 \pm 1.8$ & \\
\hline \multirow[t]{3}{*}{ HER2 } & Positive & $6.2 \pm 3.2$ & \multirow[t]{3}{*}{0.69} \\
\hline & Negative & $5.7 \pm 2.4$ & \\
\hline & Unknown (X) & $6.3 \pm 2.1$ & \\
\hline
\end{tabular}

Table 3: Relation between Human epididymal protein 4 (HE4) serum level and clinicpathological characteristic of the 120 studied cases.

\begin{tabular}{|c|c|c|c|}
\hline & & $\begin{array}{c}\text { Serum Human } \\
\text { epididymal protein } 4 \\
\text { (HE4) }(\mathrm{pmol} / \mathrm{L}) \\
(\mathrm{Mean} \pm \mathrm{SD})\end{array}$ & P value \\
\hline \multirow[t]{2}{*}{ Age } & $<40$ & $58.7 \pm 19.1$ & \multirow[t]{2}{*}{0.01} \\
\hline & $\geq 40$ & $90.3 \pm 31.1$ & \\
\hline \multirow[t]{2}{*}{ Tumor size } & T0-T1 & $49.4 \pm 5.5$ & \multirow[t]{2}{*}{0.000} \\
\hline & $\mathbf{T 2}$ & $61.4 \pm 12.7$ & \\
\hline
\end{tabular}




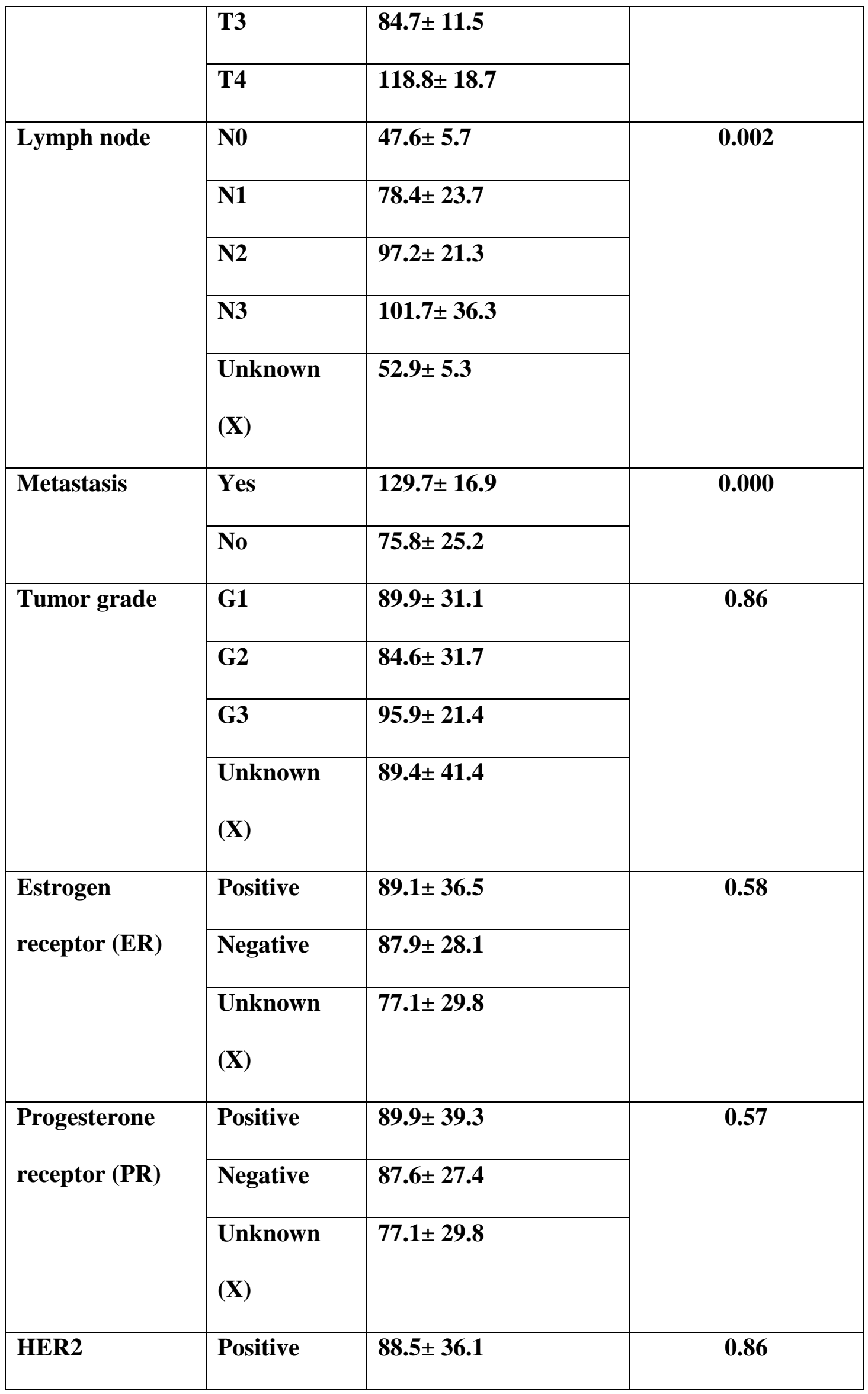




\begin{tabular}{|l|l|l|l|}
\hline & Negative & $83.9 \pm 31.6$ & \multirow{2}{*}{} \\
\cline { 2 - 3 } & Unknown & $\mathbf{8 8 . 5} \pm 32.3$ & \\
$(\mathrm{X})$ & & \\
\hline
\end{tabular}

Table 4: Serum Ki-67 level (ng/ml) and Human epididymal protein 4 (HE4) in different studied groups.

\begin{tabular}{|c|c|c|c|}
\hline \multirow[t]{2}{*}{ Markers } & & \multicolumn{2}{|c|}{ Study groups } \\
\hline & & $\begin{array}{l}\text { Healthy } \\
(\mathrm{N}=30)\end{array}$ & $\begin{array}{l}\text { Breast cancer } \\
\text { patients } \\
\quad(\mathrm{N}=120)\end{array}$ \\
\hline \multirow[t]{4}{*}{ Ki-67 (ng/ml) } & Mean \pm SD & $1.9 \pm 0.25$ & $6.1 \pm 2.3$ \\
\hline & Minimum & 1.58 & 2.13 \\
\hline & Maximum & 2.48 & 12.19 \\
\hline & $P$ value & \multicolumn{2}{|c|}{$<0.001$} \\
\hline \multirow{4}{*}{$\begin{array}{l}\text { Human epididymal } \\
\text { protein } 4 \text { (HE4) }\end{array}$} & Mean \pm SD & $19.4 \pm 2.7$ & $86.6 \pm 32.1$ \\
\hline & Minimum & 15.8 & 40.5 \\
\hline & Maximum & 25.2 & 150 \\
\hline & $P$ value & \multicolumn{2}{|c|}{$<0.001$} \\
\hline
\end{tabular}


Table 5: Correlation analysis between all the parameters under study.

\begin{tabular}{|c|c|c|c|}
\hline Parameter & $\begin{array}{c}\text { Spearman } \\
\text { rho* }\end{array}$ & Ki-67 & HE4 \\
\hline \multirow[t]{2}{*}{ Age } & $\mathbf{P}$ & \multirow[t]{2}{*}{ Insignificant, $(\mathrm{P}>0.05)$} & \multirow{2}{*}{$\begin{array}{l}\text { Insignificant, } \\
(\mathrm{P}>0.05)\end{array}$} \\
\hline & $\mathbf{r}$ & & \\
\hline \multirow[t]{3}{*}{ Tumor size } & $\mathbf{P}$ & Significant, $(p<0.001)$ & Significant, \\
\hline & & & $(\mathrm{p}<0.001)$ \\
\hline & $\mathbf{r}$ & 0.810 & 0.883 \\
\hline \multirow[t]{2}{*}{ Lymph node } & $\mathbf{P}$ & Significant, $(p<0.05)$ & Significant, $(p<0.01)$ \\
\hline & $\mathbf{r}$ & 0.290 & 0.348 \\
\hline \multirow[t]{2}{*}{ Metastasis } & $\mathbf{P}$ & Significant, $(p<0.001)$ & Significant, $(p<0.001)$ \\
\hline & $\mathbf{r}$ & 0.610 & 0.677 \\
\hline \multirow[t]{2}{*}{ Tumor grade } & $\mathbf{P}$ & \multirow[t]{2}{*}{ Insignificant, $(\mathrm{P}>0.05)$} & \multirow[t]{2}{*}{ Insignificant, $(P>0.05)$} \\
\hline & $\mathbf{r}$ & & \\
\hline \multirow{2}{*}{$\begin{array}{l}\text { Estrogen receptor } \\
\text { (ER) }\end{array}$} & $\mathbf{P}$ & \multirow[t]{2}{*}{ Insignificant, $(P>0.05)$} & \multirow[t]{2}{*}{ Insignificant, $(P>0.05)$} \\
\hline & $\mathbf{r}$ & & \\
\hline \multirow{2}{*}{$\begin{array}{l}\text { Progesterone } \\
\text { receptor }(\mathrm{PR})\end{array}$} & $\mathbf{P}$ & \multirow[t]{2}{*}{ Insignificant, $(P>0.05)$} & \multirow[t]{2}{*}{ Insignificant, $(P>0.05)$} \\
\hline & $\mathbf{r}$ & & \\
\hline \multirow[t]{2}{*}{ HER2 } & $\mathbf{P}$ & Insignificant, $(P>0.05)$ & \multirow[t]{2}{*}{ Insignificant, $(\mathrm{P}>0.05)$} \\
\hline & $\mathbf{r}$ & & \\
\hline \multirow[t]{2}{*}{ Ki-67 } & $\mathbf{P}$ & \multirow[t]{2}{*}{-} & Significant, $(\mathrm{p}<0.001)$ \\
\hline & $\mathbf{r}$ & & 0.958 \\
\hline \multirow[t]{2}{*}{ HE4 } & $\mathbf{P}$ & Significant, $(\mathrm{p}<0.001)$ & \multirow[t]{2}{*}{-} \\
\hline & $\mathbf{r}$ & 0.958 & \\
\hline
\end{tabular}




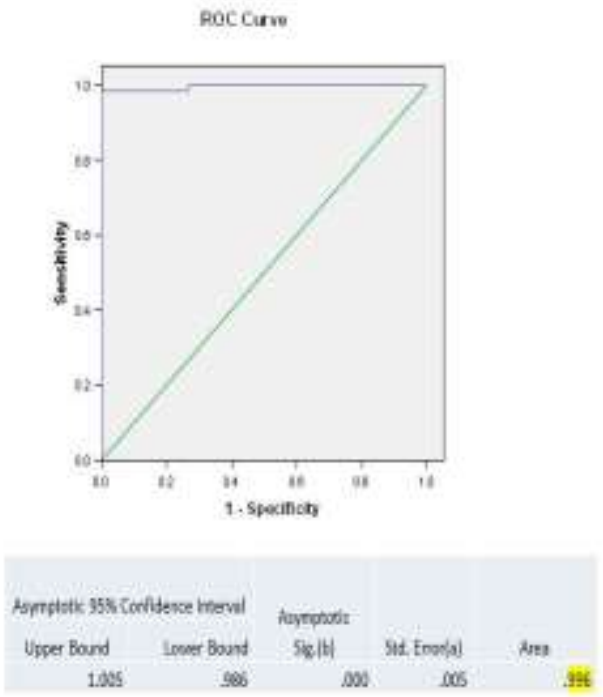

Figure 1: Figure 1. ROC curve for serum Ki-67 levels in the diagnosis of breast cancer.

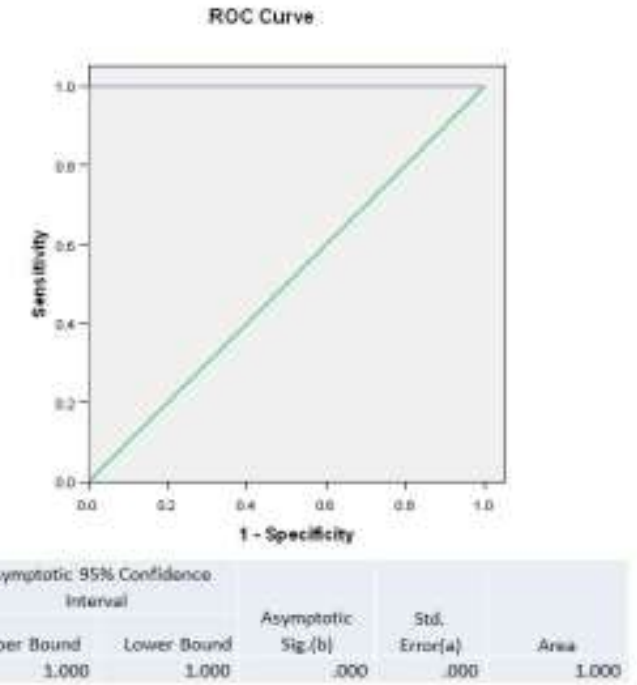

Figure 2: ROC curve for serum HE4 levels in the diagnosis of breast cancer 